\title{
10. Interpreting the Cold War
}

\author{
Michael Wesley
}

Coral Bell watched the Cold War take shape from one of ten offices in a building known as West Block, where Australia's Department of External Affairs was accommodated during the 1940s and early 1950s. There is an old saying that even the greatest diplomats never lose the desk officer's eye and fascination for the telling detail that hints at the big strategic picture; in all of Coral's writings on the Cold War one can feel her attentive mind pouring over papers, opinion and quotes, the strategist-as-detective amassing the fine detail and the telling bon mots into a masterful narrative. That Coral's first professional engagement with international affairs was as a practitioner had a lasting impact on her work; that this particular practitioner began watching the world as the reality of the Cold War became very real to Australia was to structure how she interpreted that conflict from beginning to end.

In her many writings on the Cold War, Coral always showed the practitioner's sensitivity to the often galling realities of policy-making. For example, she instinctively sensed George Kennan's frustration that, despite being in charge of Policy Planning in the State Department, he was prevented by security barriers from knowing America's actual military strength, and thus was unable to make a clear judgement about the relationship between America's commitments and capabilities. ${ }^{1}$ Coral's practitioner's view of the unfolding of the Cold War also contributed to her distinctly Anglo-centric view of the conflict. A striking thread of continuity through all of her writings on the Cold War is her determination to make the point that the free world was not led by America alone, but by an Anglo-American condominium. As David Lowe and Christopher Waters chronicle, the early years of the Cold War saw a resurgence of Anglophilia in Australia, which the Pacific War and the American alliance had eroded during the 1940s. ${ }^{2}$ Between 1948 and 1952, Australia's strategic preoccupations changed from regional worries about Japan's resurgence to global concerns about the Cold War - and to supporting the Anglo-American cause in the global struggle with communism. Coral was at pains to point out at several junctures that the eventually successful western strategy in the Cold War, from the Marshall Plan to the 'scaffolding' that became NATO to the integration of West Germany into the western alliance was as much London's as Washington's design. Indeed,

1 Coral Bell, Negotiation from Strength: A Study in the Politics of Power, Chatto \& Windus, London, 1962, p. 36.

2 David Lowe, Menzies and the 'Great World Struggle': Australia's Cold War, 1948-1954, UNSW Press, Sydney, 1999; Christopher Waters, The Empire Fracture: Anglo-Australian Conflict in the 1940s, Australian Scholarly Publishing, Melbourne, 1995. 
there is more than a hint of Harold Macmillan's belief that Britain could play the tempering role of the 'Greek' nuance and intellectualism in strategy to the Americans' 'Roman' muscle when she observed that the design for NATO was actually 'a return to the long-standing British tradition of a continental alliance as the basis of a balance of power coalition against any new potential contender for European hegemony'. ${ }^{3}$

But none of this is to argue that Coral Bell was either a detail-mired pedant or a slavish Anglo-booster. What really emerges from her writings on the Cold War is the mind and judgements of a master strategist. Without being cased in the ponderous methodology or self-congratulatory philosophics of American and British international relations, the theoretical and conceptual gems that pepper her Cold War writings nestle amidst her elegant prose, guaranteed to cause the reader to pause and look into the middle distance regularly. Her wonderful use of level-of-analysis reasoning (without ever referring to that awful phrase) to distinguish between containment and negotiation-from-strength is one example. ${ }^{4}$ Her incisive contribution to alliance theory, in terms of a balance between 'net producers' and 'net consumers' of security, is another. ${ }^{5}$

Coral was also a thinker who had the uncanny knack of previewing debates and controversies decades before others were to use them to make their names. Her discussion of mutually-abrasive values systems arising from the empowerment of newly-independent states, particularly in the wake of the Khomeinist revolution in Iran, prefigured Bull's and Watson's writings and Huntington's 'clash of civilizations' by years. ${ }^{6}$ Similarly her considerations of the rise and origins of America's neoconservatives, and their philosophical and policy differences from realists and liberals, preceded the arrival of the George W Bush administration by well over a decade. ${ }^{7}$ In retrospect, Coral's clear and balanced discussion of the neo-cons, with its subtle undercurrent of irony, stands as still the best there is, even after the avalanche of analyses that accompanied the Bush years.

The Cold War was the conflict that animated Coral Bell's writings. She pushed and probed at the confrontation, teasing out the inner logics of its grand strategies and concepts and subjecting them to the judgement of her incisive mind. Even when she confined herself to writing about Australia, she began and ended her

3 Coral Bell, The Cold War in Retrospect: Diplomacy, Strategy and Regional Impact', Working Paper no. 298, Strategic and Defence Studies Centre, The Australian National University, Canberra. 1996, p. 3.

4 Bell, Negotiation From Strength, p. 30.

5 ibid., pp. 172-173.

6 Coral Bell, President Carter and Foreign Policy: The Costs of Virtue?, Canberra Studies in World Affairs, The Australian National University, no. 1, 1980, pp. 100-101

7 Coral Bell, The Reagan Paradox: American Foreign Policy in the 1980s, Edward Elgar, Aldershot, 1989, pp. 5-12. 
analysis with the 'central balance'. ${ }^{8}$ She never tried to set herself the task of writing a grand all-encompassing account of the Cold War, probably precisely because the practitioner in her knew such a task would see the telling detail be overwhelmed by the straitjacket of narrative; the scholar in her probably also knew that the analytical meat lay in isolating and investigating aspects of the bigger conflict. To my reading, Coral Bell interpreted the Cold War according to six broad preoccupations. Some of these preoccupations animate a single book or article. Others run through the long period of her scholarship, and with each return, a different aspect of the preoccupation is explored. Each on its own stands as a major contribution to Cold War scholarship; together they constitute a remarkable monument to understanding the defining stand-off of the twentieth century.

\section{Democratic Alliances Versus Authoritarian Blocs}

The earliest preoccupation in Coral Bell's Cold War writing is with whether democracies in an alliance are able to muster the will, strength and flexibility to prevail in a contest with an authoritarian bloc. Negotiation From Strength can be read as an extended analysis of the disadvantages of democratic decisionmaking and alliance management and strategising in an extended low-intensity confrontation such as the Cold War. Her ultimate conclusion is that, during the first decade of the Cold War, an alliance of democracies was unable to summon either the strength or to choose the right time to negotiate based on a judgement of the most favourable correlation of forces. While her apprehensions about the authoritarian advantage in strength and negotiation were inevitably to wane with the passing of the years, Coral's sober pessimism about democratic strategising and alliance politics remained undimmed.

From the start, Coral regarded military alliances as a necessary weakness for the United States. While Washington needed a strategic foothold and eventual arsenal in western Europe, it bought these at the cost of difficult and at times all-consuming alliance relations. 'There are', she wrote,

two surprising things about the history of NATO. The first is that its strategic concepts have borne so little relation to the ostensible political or diplomatic ambitions of its members. The second is that though the states to whom was allotted the task of raising the forces proposed for the Central Front have included some of the most notable and successful

8 Coral Bell, 'The Central Balance and Australian Policy' in Coral Bell (ed) Agenda for the Eighties: Contexts of Australian Choices in Foreign and Defence Policy, Australian National University Press, Canberra, 1980. 
military powers in modern history ... they have never succeeded in reaching actual force figures commensurate with even their minimal strategic objectives, ... a politically dismaying demonstration of their inability to match intention and performance unless the knife is at their throats. ${ }^{9}$

For Coral, the problem had two parts: democracy and alliances. Each seemed to exacerbate the inability of the other to function effectively. Alliances seemed to mire strategy in a form of collective small-mindedness: 'in the nature of things, the ability of an alliance to pursue a common policy is limited and conditional: limited and conditioned by the behavior of the putative enemy, the lowest common denominator of individual cost and the highest common denominator of individual interest ${ }^{\prime}{ }^{10}$ Democracy on the other hand was the constant enemy of the strategist, be he Acheson, Dulles, Kissinger or Bzrezinski. Populism was heightened by the constant tension of the Cold War, forcing American policymakers towards decisions that brought strategic disadvantage. Democracy foregrounded morale and mood as the key ingredient of Cold War policymaking: on reading Coral's account of the psychological impact on America of the triple shocks of 1949- the communist victory in China, the Soviet nuclear test, and the discovery of communist spies in the American government-one is left in little doubt about the constraints under which the Truman administration was acting. ${ }^{11}$

It was perhaps the difference in unity and resolve between the Cold War and the Second World War that was most dismaying. Coral was pessimistic about the 'political limitations on the ability of a government in a democracy to pursue an unpopular course of action in a period of less than immediate crisis' ${ }^{12}$ The problem was that in conditions of crisis, 'decisions had to be taken at great speed, with little leisure for reflection on the limits they might later impose on the negotiating position of the West' ${ }^{13}$ In the final analysis, the West's ability to build requisite strength in the Cold War's first decade was the result of failures in leadership, the nature of democratic institutions, and the commitment to pluralistic decision-making within countries and across the alliance. ${ }^{14}$ On the other hand, the time at which it was most advantageous to negotiate with the Soviet Union from a position of comparative strength, Dulles was unable to do so because of the hyper-aroused state of the domestic political climate.

9 Bell, Negotiation from Strength, p. 46.

10 ibid., pp. 202-203.

11 ibid., pp. 76-77.

12 ibid., p. 47.

13 ibid., p. 47.

14 ibid., p. 191. 
Coral seemed to shift in her thinking over time about whether grand strategic coups were within the capacity of democracies. At the end of Negotiation From Strength she concludes that democratic strategising must be from necessity about pragmatism, the finding of least-worst outcomes, a 'sophisticated Micawberism' ${ }^{15}$ A couple of decades later, she was not so sure. Kissinger's grand strategising as the animation of the policy of détente emerges as a case where a democracy considerably outpaces sophisticated Micawberism. ${ }^{16}$ Carter's 'sho 'nuff' earnest idealism emerges as a more unfortunate example, ${ }^{17}$ while Reagan's calculated bravura is judged more favourably. ${ }^{18}$

\section{A Study in Competitive Psychology}

Coral Bell's intuitive power is best and repeatedly illustrated by her focus on issues and tendencies that at the time were not widely known or discussed, but which later became defining frameworks of analysis. One such remarkable example occurs late in Negotiation From Strength, in which her discussion of the competitive psychology of Cold War strategy clearly anticipates by nearly two decades Daniel Kahneman and Amos Tversky's defining work on prospect theory and decision bias. While Kahneman and Tversky's theories were based on painstaking empirical research, Coral comes to very similar conclusions based on sheer deductive intuition.

She begins with a careful discussion of the clear conceptual differences between status quo and revisionist strategies in the Cold War. Unlike Kissinger and others who were inclined to label entire foreign policies status quo or revisionist, Coral pointed out that there were elements of status quo-ism and revisionism in both American and Soviet policy. 'There is a stronger unconscious element of revisionism in American foreign policy attitudes than Americans are usually prepared to perceive', she wrote. That revisionism was the constant desire to make the world more compatible with American principles and interests. Soviet revisionism came from the same motivation. Negotiation from strength, in these terms, meant 'an effort to improve the balance of military power, and to use your new position to seek a new status quo of a more satisfactory sort' ${ }^{19}$ But the revisionist policy of each threatened the status quo perceptions of the other; thus 'issues like Berlin are obviously not only important in themselves but important as psychological rallying points. The status quo is physically expressed in a number of territorial arrangements, and the demand to change

\footnotetext{
ibid., p. 189.

16 Coral Bell, The Diplomacy of Détente: The Kissinger Era, St Martin's Press, New York, 1977.

17 Bell, President Carter and Foreign Policy.

18 Bell, The Reagan Paradox.

19 Bell, Negotiation from Strength, p. 201.
} 
one of them is heavy with psychological significance'.$^{20}$ Therefore, 'faced with the clear prospect of encroachment on its sphere of power by a dangerous enemy, a nation may stake its survival on resistance to that encroachment ... especially in a period in which the memory of Munich has been invoked unceasingly to prove that whenever anything is conceded, everything is lost' ${ }^{21}$

On accepting the Nobel Prize in 2002, Kahneman said that his and Tversky's most important discovery was a pervasive decision bias they named 'loss aversion': the widespread human tendency to forego the chance of making a gain if taking that chance could also result in a loss. This had been detailed in a breakthrough article in 1979. ${ }^{22}$ Here is Coral Bell, writing in 1962:

The prospect of loss is a stronger motive in international affairs, as in individual ones, than the hope of gain. This may not be logical, but it is reasonable enough. The powerful forces of anger and immediate fear reinforce calculation when loss is in question: where it is a matter of gain only a remoter fear can be enlisted to aid calculation, and a heavy inertia exists to dampen its schemes. ${ }^{23}$

So much depends on this insight into psychology:

A rich and happy country like America will not stake much for the hypothetical advantages of increasing its sphere of power. ... A revisionist policy likely to incur serious costs, even in the form of conventional warfare, would be difficult for a prosperous democracy to contemplate. ... A revisionist policy backed solely by the power of a nuclear strike would surely be possible only in a pathological state of political opinion. ${ }^{24}$

Not content with this powerful insight into American motivations, Coral then applied it to the Soviet Union's. While conceding that Moscow was status quooriented in relation to its sphere of power in Eastern Europe, she argued that 'Russian power is, in aspiration, revisionist a l'outrance [in seeking] not only an ultimate total remaking of the power map of the world but a transformation of the nature of the whole society of states' ${ }^{25}$ Moscow had discovered during the Suez Crisis, she argued, that by backing revolutionary urges in the Third World, it could invest in a revisionist policy with little threat to its status quo interests in Eastern Europe: 'So there is a sense in which it can be said that the

\footnotetext{
ibid., pp. 199-200. 
Russians have been able to use their air-atomic power as psychological backing for revisionist political objectives' ${ }^{26}$ Ever on the outlook for the telling bon mot, one can sense Coral's delight when she came across Khruschev's quote in a Walter Lippmann interview that 'the revolution is the status quo'. ${ }^{27}$

Two further complications add to the psychological disadvantage of the West in the competition with the Soviet bloc. The first is military technology, which has constricted decision parameters and response options: 'the revolution in military technology has operated to displace status quo by revisionist intentions at a moment of crisis, since the military operations logically required merely to ensure national survival have become identical with those required by the most sweeping revisionism'. ${ }^{28}$ The second is the psychological effects of self- and other-images widespread among Americans:

$[\mathrm{T}]$ he rather flattering and unrealistic persona that western opinion ... constructs of its own character in international dealings - an essentially law-oriented, reasonable, even idealistic self-image - is not compatible with the degree of ruthlessness implied [by negotiation from strength]. Whereas the qualities we impute to the Russians, especially their alleged disregard for the human costs, even within Russia, is entirely compatible. Thus the West tends to be hoist with its own psychological warriors' petard: the Cold War image of Russian society, constructed with some deliberation in the West, becomes in itself a means of diplomatic leverage to the Russians. ${ }^{29}$

\section{A Game of Shifting Momentums}

Whether discussing democratic passions, alliance politics or the complexities of competitive psychology, the hydrographic metaphor of momentum seemed never far from Coral Bell's elbow. She talked from a very early stage about the shift in momentum within NATO from the United States to Europe, just as she observed Moscow's pragmatic tilt behind the momentum of Third World radicalism and Western defensiveness. And it was a hydrographic sense of advantage and disadvantage that fired her implacable conviction of the folly of the Vietnam War. The war in Vietnam was for her a 'painful and damaging misapplication of the strategy' of containment: 'The metaphor [for containment] always used, from the earliest days, was that of a dam, holding back relentless pressure. But 
what use is a dam if it is built on sand?'30 The conditions that existed in Vietnam, which were apparent at the time, meant "the "dam of containment" was always built on sand: politically, morally, militarily, even legally'. ${ }^{31}$

Coral's critique of the Vietnam War offers a clue to her understanding of containment as a grand strategy of the Cold War. Containment was never about building a perimeter fence around the extent of world communism, but rather was about identifying and fortifying a set of points of strength to be prosecuted consistently. ${ }^{32}$ For Coral, strategy within containment must be based on a careful calculation of the balance-of-momentum: to make a stand at a point where the momentum is against you will result in a much more significant setback than just a tactical defeat. The hydrographic nature of the struggle meant that regional defeats like that in Vietnam could turn the momentum against the West in the central balance against the Soviet bloc.

It was unsurprising, then, that when Coral Bell looked back from the mid-1990s on the Cold War that had ended, that she relied heavily on a hydrographic metaphor of shifting advantage and disadvantage to tell the story of what happened. ${ }^{33}$ The first decade was defined by rapidly oscillating initiative on either side of Eurasia - first in Berlin, then in Korea. The second decade saw the Soviet bloc gain the initiative, particularly among the revolutionary forces in the Third World. The third decade saw the initiative flow back to the peripheries of the Western alliance through the economic ascendancy of Germany and Japan. This showed the apparent Soviet momentum to be hollow, by demonstrating that war-devastated capitalist economies were comprehensively out-performing their war-devastated communist counterparts. The fourth decade saw the momentum continue to shift towards the West despite what appeared on the surface to be a losing streak between 1965 and 1980; while the fifth decade saw the Soviet Union unravel as it desperately tried to rebalance the strategic momentum against it.

For Coral Bell, momentum was about structure and agency. There were some elements of momentum that just happened as a consequence of the forces of history: one example is the rise of Third World radicalism in the 1950s and 1960s; another is the outbreak of revolutionary Islam in the 1970s and 1980s. But momentum for Coral- like fortuna for Machiavelli - is a force that needs to be understood and manipulated with wisdom and courage, lest it lead to ruin. To Coral's mind, Stalin and Khruschev made crucial errors in overplaying their hands when they thought momentum was with them. Stalin's obduracy led to a

\footnotetext{
30 Bell, The Cold War in Retrospect, p. 8.

31 ibid., p. 9.

32 John Lewis Gaddis, Strategies of Containment: A Critical Appraisal of Postwar American National Security Policy, Oxford University Press, Oxford, 1982.

33 Bell, The Cold War in Retrospect.
} 
tightening of the NATO alliance that would never have occurred without him; ${ }^{34}$ while Khruschev's cocksure shoe-pounding led Third World leaders to make ever more aggressive moves emboldened by the prospect of Soviet air support that never quite showed up. ${ }^{35}$ In the end, it was a B-grade actor's sense of timing, messaging and proportion that harnessed building momentum without over-playing it, that brought an astonishingly sudden and peaceful end to the confrontation. ${ }^{36}$

\section{Power Versus Values}

The presidencies of Jimmy Carter and Ronald Reagan stimulated in Coral Bell an interest in values as means and ends in the Cold War. Prior to the late 1970s and 1980s, the ideological aspect of the Cold War had interested her only insofar as they affected the power and resolve of the two sides. Thus democracy, while no doubt an important system of values for Coral personally, was for a long time of scholarly interest only in terms of how it affected the West's capacity to act decisively and direct resources to strategic ends. Or when self-images of constitutionalism and moderation led to a psychological disadvantage in strategic manoeuver vis-à-vis an opponent depicted as authoritarian and deaf to the suffering of its own people.

But in Carter and Reagan the Cold War gained two primary protagonists who insisted at putting values to the fore. It was Carter and Reagan that brought to the fore the fact that the Cold War was a conflict played out on two planes - one between power systems, the other between values systems. ${ }^{37}$ Coral found the similarities between the two administrations as intriguing as their differences. In the end she judged the Reagan team's 'right-wing Utopianism' to be the mirror image of the Carter administration's 'left-liberal Utopianism'. ${ }^{38}$ She was particularly intrigued that many of the neo-cons who became Reagan's early cheer squad had begun their political lives on the radical left.

Ultimately, however, there is little doubt that Coral Bell saw the power conflict as the primary contest, the values conflict as secondary. Despite the rising emphasis on values in the West, on both the right and left, 'the maintenance of the Western value-system, which proposes those ideals among others [that is, human rights, development], depends in the last analysis on the maintenance of its power-position vis-à-vis adversaries proposing alternate values systems' ${ }^{39}$

34 ibid., p. 17.

35 Bell, Negotiation from Strength, p. 213.

36 Bell, The Reagan Paradox.

37 Bell, President Carter's Foreign Policy, p. 100.

38 Bell, The Reagan Paradox, p. 139.

39 Bell, President Carter's Foreign Policy, p. 2. 
For Coral, Kissinger had prioritised the power contest over the values contest to great effect - including for the West's cause in the contest of values, as enshrined in the Helsinki Final Act. ${ }^{40}$ Carter prioritised value-system conflict and ended up losing on both planes. On the power-plane, while an emboldened Soviet Union went on the offensive in the Americas, Asia and Africa, the West lost crucial allies in Iran and Ethiopia. On the values-plane Carter found himself forced into a range of compromising choices, including upholding the Khmer Rouge's right to Cambodia's seat at the United Nations. ${ }^{41}$ Reagan too found values to be a cruel mistress, leading him to embarrassment in Iran and Nicaragua. ${ }^{42}$

Ultimately, Coral believed values were a dangerous commodity as an ends or a means in the Cold War. Power is cold and passionless; conflicts over power can be divided, bargained, negotiated. 'Value-oriented foreign policy', on the other hand, 'usually tends to make international relations more abrasive than a poweroriented diplomacy, because on the whole it is more difficult to compromise values than to divide or offset power' ${ }^{43}$ In the rise of Khomeini, Coral could foresee a post-ideological age of values conflict, centred around religion and cultures. She wondered about the consequences of the possible rise of Indian, Japanese and African value systems driven by the same intensity as Khomeini's Iranian revolution, for the future of world order.

For Coral, the discussion of power came easier than the discussion of values. It was as if power was a more workable medium for her mind. Perhaps her most acute encapsulation of the grand strategies of the Cold War came in the midst of her discussion of one of the most values-driven American administrations:

All recent Administrations in Washington have had in essence two basic tasks in international politics. First, managing the adversary relationship with the Soviet Union so that it produces neither war nor Soviet victory without war; and secondly, managing a set of relationships with the rest of the world which have inescapably become those of reduced US paramountcy. ${ }^{44}$

She could have easily extended the same analysis to the strategic goals of the Soviet Union, and thereby neatly summarised the whole of the Cold War.

\footnotetext{
Bell, The Diplomacy of Détente.

Bell, President Carter's Foreign Policy, p. 93.

Bell, The Reagan Paradox.

Bell, President Carter's Foreign Policy, p. 100.

4 Bell, The Reagan Paradox, p. 141.
} 


\section{Words Versus Actions}

The Reagan Paradox is to my reading the most systematic of Coral Bell's analyses. It begins with an analytical framework that contrasts declaratory policy from operational policy, a distinction that was suggested to her by an article written by Paul Nitze on the foreign policy of John Foster Dulles in the 1950s. Both declaratory signalling - the spoken intent of a government - and operational signalling - the actual actions of a government - are important in the strategic dialogue that occurs between adversaries and allies. Although she plainly sees operational policy as the real thing (she re-uses a French adage that the soup is never eaten as hot as it is cooked' to observe, 'The hot soup of declaratory policy ... is necessarily cooled a bit by the breath of pragmatism before it is served as policy ${ }^{45}$ ), she is clearly intrigued by the real-world effects of declaratory signalling. While the focus on declaratory signalling by the Reagan administration is explicit, it is by no means the first time it caught Coral's attention. As far back as Negotiation From Strength she was intrigued at the real strategic payoffs that accrued to the Soviet Union in the Third World from its sabre-rattling during the Suez Crisis. ${ }^{46}$

Coral argued that both declaratory and operational signalling were crucial to the Cold War's dynamics because they informed the expectations that each side had of the other, which in turn were incorporated into assessments of the costs and risks that informed the policy decisions of each side. More specifically, operational and declaratory signals provided the best impression of each side of the other's will. This was even more the case in the dawning 'age of surveillance' of the 1970s and 1980s, because 'the remaining ambiguities of the power balance are mostly in the area of will rather than capacity, and declaratory signals tend to determine the image of will which each group of adversary decision-makers forms of the other' ${ }^{47}$

The distinction between declaratory and operational signalling was used by Coral to explain the paradoxical success of the Reagan administration in bringing on the reforms in the Soviet Union that eventually led to its collapse. She argued that it was Reagan's uncompromising declaratory signalling, from his quips about the next world war to his 'evil empire' rhetoric, that forced Moscow into a strategic corner, unable to compete and unwilling to concede. On the other hand, Reagan's mild and conciliatory operational signalling prevented the competition from boiling over into open confrontation, and prepared the ground for a new and terminal period of détente. Ultimately, the most effective declaratory signal was the 'Star Wars' missile defence program, which Coral argued the Soviets

45 ibid., p. 7.

46 Bell, Negotiation from Strength, pp. 204-205.

47 Bell, The Reagan Paradox, p. 23. 
over-interpreted thanks to their own defence doctrine: 'Soviet standard military doctrine teaches that a strategic defensive move must be linked with a strategic offensive concept to conduce to victory. Therefore, Soviet analysts were more likely than Western ones to see a coherent strategic offensive design behind the defensive shield President Reagan kept talking of' ${ }^{48}$

Ultimately, Coral's analysis of the differential effects of Reagan's words and deeds on Soviet calculations is unconvincing. It is hard to see why a confrontationseasoned Politburo would have been simultaneously calmed by mild operational signalling while at the same time panicked by Reagan's tough-guy declaratory rhetoric. But even if one is unconvinced of her specific argument, it remains that one is still greatly enriched in having followed her reasoning and been challenged by her insights.

\section{The Cold War as a Stage}

Ultimately, it is impossible to read Coral Bell's writing on the Cold War and not be beguiled by the cast of characters she assembles: the wise, the cunning, the gormless, the bombasts. Perhaps the most persistent theme of her Cold War writing was to see that overarching conflict as a crucible in which policy-makers' character, judgement, luck and guile were put to the test. There are glimpses of consideration of structural forces in her work; she admits that 'the comparative quiet of the first Reagan term could have been seen as a natural consequence of Soviet activism in the Carter years. Reagan, in other words, then enjoyed the good fortune of Carter's bad fortune' ${ }^{49}$ But these are just glimpses. For Coral Bell the Cold War was ultimately a Shakespearean test of the mettle of statesmen.

Coral is as pitiless at assigning blame as she is generous in giving credit. Thus Stalin emerges repeatedly as the great bungler, overreaching in Europe and Korea and ensuring an implacable Western alliance and an isolated and increasingly weak Soviet bloc that will lose the Cold War. Repeatedly she wonders what would have happened had Stalin, rather than Roosevelt, died in 1945. On the other hand, there are those she admires. Ernest Bevin joins Kennan, Acheson, Dulles and Kissinger as the wise strategists who charted the West's course through the conflict. She is much less kind to the members of the Carter and Reagan administrations; in the end the positive momentum established by both appears more the result of Soviet over-reach than an American Svengali.

Despite her attention to the hard politics and strategic choices of the Cold War, Coral Bell was always attentive to the winners and losers. Repeatedly she asks

48 ibid., p. 35.

49 ibid., p. 53. 
who won and who lost from a particular passage of the confrontation. Winners and losers could be alliance systems or countries; at other times she was very attentive to the women of Iran under the Khomeinist revolution. It was these considerations that bring home the fact that for Coral Bell the Cold War was always a personal, human consideration. It was probably a conviction that began as the confrontation started, in one of those ten rooms in West Block. 
This text taken from Power and International Relations:

Essays in honour of Coral Bell, edited by Desmond Ball and Sheryn Lee, published 2014 by ANU Press, The Australian National University, Canberra, Australia. 